\title{
Timber transported to Antarctica: a potential and undesirable carrier for alien fungi and insects
}

\author{
Piotr Osyczka • Piotr Mleczko • \\ Dariusz Karasiński • Andrzej Chlebicki
}

Received: 27 January 2011 / Accepted: 1 April 2011/Published online: 19 April 2011

(C) The Author(s) 2011. This article is published with open access at Springerlink.com

\begin{abstract}
Antarctica's severe climate and its geographical isolation are the factors that hinder the arrival of non-native species by natural means. However, the movement of people and cargo associated with national scientific programs and tourism render Antarctica much more accessible to exotic organisms. Both the transport routes and carriers are varied. The wide range of uses to which timber is put means that it is readily freighted to Antarctic stations. However, it can harbor numerous alien organisms. All the timber materials transported to the "Arctowski" station for the 32nd Polish Antarctic Expedition in the 2007/2008 season were scanned as a potential vector for alien species. This study focuses on the non-lichenized fungi and insects which were found on the timber. Four species of perithecia-forming Ascomycota, five species of corticioid and polyporoid Basidiomycota, four
\end{abstract}

P. Osyczka $(\bowtie)$

Department of Polar Research and Documentation, Institute of Botany, Jagiellonian University,

Kopernika 27, 31-501 Kraków, Poland

e-mail: piotr.osyczka@uj.edu.pl

P. Mleczko

Department of Plant Taxonomy and Phytogeography, Institute of Botany, Jagiellonian University,

Lubicz 46, 31-512 Kraków, Poland

D. Karasiński · A. Chlebicki

Department of Mycology, W. Szafer Institute of Botany,

Polish Academy of Sciences, Lubicz 46,

31-512 Kraków, Poland unidentified basidiomycetes taxa in form of sterile mycelia, and two insects belonging to Cerambycidae, were detected. Most of these 'hitch-hikers' were connected with the untreated parts of the timber. Their enduring survival in harsh Antarctic conditions is regarded as highly improbable. Nevertheless, some ascocarps frequently contained vital spores, and live insect larvae and imago were found in hibernation. The results also emphasize that such organisms can be accidentally transported to Antarctica and that the elementary rules for the eventual safe transport of noninfected goods should be obeyed and respected.

Keywords Non-native - Human impact - Cargo · Wood $\cdot$ Removal $\cdot$ Antarctic conservation

\section{Introduction}

The geographic isolation and harsh climate of the Antarctic region mean that it appears to have remained the most unaltered and natural part of the world. Taken in a worldwide context, human activity in the region has been neither lengthy nor intensive. However, the current increase of human activity at research stations, transport and tourism threaten the uniqueness of the Antarctic environment. Most operations are concentrated around nearly 80 seasonal or year-round national stations and the highest density of settlements lies just south of $60^{\circ} \mathrm{S}$ latitude, 
in the relatively accessible area of the maritime Antarctica (Council of Managers of National Antarctic Programs (COMNAP) 2010). Owing to the relatively safe navigation and sight-seeing attractions, tourism is also focused on this area (International Association of Antarctica Tour Operators (IAATO) 2010). The maritime Antarctic is thus under particular human pressure.

According to Frenot et al. (2005), a non-native species/alien is an organism introduced to an ecosystem as a result of human activity; this includes species that arrive by natural means but are not native to a given biogeographical zone. The appearance of an alien invasive species in a natural environment might threaten the native components and has major impact on global biodiversity (e.g. Sala et al. 2000). In spite of the fact that the exploration of the Antarctica is relatively recent, the problem of the transport and introduction of non-native species by human means has also begun to affect that region and to increase in last years. The simplicity and isolation of Antarctic ecosystems render them more susceptible to alien invasion (Hughes et al. 2006). More attention is thus currently being devoted to the phenomenon of both the real and potential introduction of alien organisms to native Antarctic communities (e.g. Convey et al. 2006; Hughes and Convey 2010; Hughes and Worland 2010; Hughes et al. 2010).

The ice cover and severe climate dramatically reduce the occurrence of terrestrial organisms in Antarctica. The simplicity of the ecosystems emphasizes the fact that only two native vascular plants occur in the region and their existence is limited to the Antarctic Peninsula. Consequently, vegetation is very scarce and the Antarctic tundra is dominated by cryptogams (e.g. Olech 2004), while the invertebrate fauna mainly consists of microarthropods (Block 1984). However, the biodiversity is increasing as a result of the human presence and many non-native species from a wide range of living organisms have been introduced (Hughes and Convey 2010). The recent intensive deglaciation process and climatic changes observed over the past few years in Antarctica (Convey 2006) have reduced the severity of the climate and increased the risk of alien species becoming permanently established.

Organisms, or their propagules, can be transported by humans to Antarctica on different carriers, e.g. clothes, vehicles, aircraft and ship holds, food, cargo, sand, aggregate, wood, and other building materials (see Whinam et al. 2005). In an area devoid of trees, wooden materials are especially valuable and timber in various forms is thus delivered to Antarctic stations.

Untreated fragments of wood, with the bark still attached, delivered to the "Arctowski" station, King George Island, South Shetland Islands, in the 2007/2008 season turned out to be a significant vector for several alien lichen species (Osyczka 2010). This paper focuses on the non-lichenized fungi and insects associated with this timber.

\section{Materials and methods}

\section{Sampling area (station)}

The "Arctowski" is an all-year-round medium sized station located on the west shore of Admiralty Bay at $62^{\circ} 09^{\prime} \mathrm{S}$ and $58^{\circ} 27^{\prime} \mathrm{W}$. Detailed specifications can be found on the station's official website, at http://www. arctowski.pl/index.php?p=196. The whole Admiralty Bay comes under Antarctic Specially Managed Area (ASMA) No. 1. In addition, Antarctic Specially Protected Area (ASPA) No. 128 was established to the south of the station; this being the former Site of Special Scientific Interest (SSSI) No. 8.

\section{Sampling and specimen examination}

The shipment put together for the 32nd Polish Antarctic Expedition in the 2007/2008 season contained various timbered structures, such as planks, scantlings, stumps, stiffen bundles, wooden pallets, and cages and crates, as well as the remnants of branches or twigs hidden in crates of fruits and so forth. Once they had been unloaded, all these elements, stored inside or outside the station buildings, were successively scanned, with particular attention being paid to the parts still covered with the remains of the bark. All the fruit bodies of fungi were gathered with substrate, air dried and packed into envelopes. Insect larvae and imago were placed in vials with $70 \%$ ethanol. All the samples were then taken back to Poland.

The fungal material, larvae and imago were examined with the aid of dissecting and lightmicroscopes and identified using the appropriate 
and standard methods. All the specimens have been preserved in the Lichenological Herbarium of the Institute of Botany at the Jagiellonian University (KRA) and are available upon request.

\section{Results}

The timber brought to the "Arctowski" station from Poland turned out to be an undesirable harbor and carrier for several alien fungi and two species of insects. Under this study, four species of Ascomycota and five species of Basidiomycota, together with four unidentified basidiomycete taxa, were apprehended and peritecia-forming ascomycetes and corticioid and polyporoid forms of basidiomata were found to be present. The sterile mycelia of unidentified basidiomycetes were also detected. One species of insect was represented by both the larva and imago (female), while the second one was only caught in larva form. All the pieces of timber gathered and examined were hardwood. Table 1 provides detailed information on the taxonomic affiliation of the species, their global distribution, the potential or real vitality of the individual specimens taken and the number of specimens detected.

\section{Discussion}

The harsh environmental conditions of Antarctica do not support the development of a diverse ascoor basidiomycetes biota and entomofauna (see: Vernon et al. 1998; Bridge et al. 2010). Some fungi have a range of morphological and physiological adaptations, such as the capacity to dehydrate, and to produce antifreeze compounds, a freezing tolerance, survival under anoxia and resistance to high UV radiation, which allow them to exist in the Antarctic region (Magan 2007; Ruisi et al. 2007). Currently, around 500 species of fungi are known from the area south of $60^{\circ} \mathrm{S}$; what is important, however, is that only $2-3 \%$ are considered to be truly endemic (Bridge and Hughes 2010). The majority of recorded taxa are microfungi belonging, predominantly, to Ascomycota. Fruiting bodies-forming Basidiomycetes are represented by only few species connected with mosses or organic debris (e.g. Pegler et al. 1980). To date, no species of fungi producing large fruit bodies on wood have been reported from Antarctica (Bridge et al. 2010). Some insects, which are able to survive the formation of ice in their tissues, are characterized by freezing tolerance but, generally speaking, an indigenous, free-living entomofauna is extremely rare to Antarctica (Vernon et al. 1998). Only two native 'higher' insect species are present in areas of the northern Antarctic Peninsula (Block 1984).

Nevertheless, the recent climate changes, which are ameliorating environmental conditions, combined with intensified human activities, are promoting a rapid increase of biodiversity in Antarctica. Numerous observations have been published on unintentional import of alien fungi and insects which survive and become in association with Antarctic research stations (e.g. Hughes et al. 2005). Moreover, the fungi, including ascomycetes, present in the intestines of larvae have been quoted as example of potential multiple introduction from a single invertebrate importation (Bridge and Denton 2007).

Most of the alien lichens accidentally transported to the "Arctowski" station in the 2007/2008 season were associated with untreated timber (Osyczka 2010). It turns out that non-lichenized fungi and insects can also be transported in this way. In this paper, we present data on thirteen fugal and two insect taxa which were thus imported. It can be assumed that the basidiocarps mentioned in the paper developed either in Poland or during shipping. The latter possibility is suggested by the colorless, fertile specimens of Chondrostereum purpureum and Bjerkandera adusta which had clearly formed in the absence of solar light, for example, in the ship's hold. The same could probably be said for ascocarps. However, in this case, the possibility that they might also have developed, or continued developing, after arrival to the station cannot be excluded. Vital spores found inside the said ascocarps suggest this eventuality. Nonetheless, it is also possible that some basidiocarps and ascocarps were already dead when they arrived in Antarctica.

We have assumed that the probability of that imported fungi and insects will become established and spread can be considered as rather negligible. In all cases, they have a temperate distribution pattern (see Table 1). The production of fruit bodies by all the recorded fungi, and life cycles of insects, are associated directly with bark. Even if the insects were to 
Table 1 Fungi and insects accidentally transported with timber via a shipment to the "Arctowski" station during the 2007/2008 season

\begin{tabular}{|c|c|c|c|c|}
\hline Affiliation & Species & Number of specimens & $\begin{array}{l}\text { Potential or real } \\
\text { vitality }\end{array}$ & Distribution pattern \\
\hline \multicolumn{5}{|l|}{ Fungi } \\
\hline \multirow[t]{4}{*}{ Ascomycota } & $\begin{array}{l}\text { Hypoxylon fragiforme } \\
\text { (Pers.) J. Kickx f. }\end{array}$ & $\begin{array}{l}\text { Several stromata in different } \\
\text { stages of development }\end{array}$ & Vital spores & Northern Hemisphere \\
\hline & $\begin{array}{l}\text { Nectria coccinea } \\
\text { (Pers.) Fr. }\end{array}$ & Several groups of perithecia & $\begin{array}{l}\text { Status undefined } \\
\text { (probably no } \\
\text { vital spores) }\end{array}$ & $\begin{array}{l}\text { Europe, Asia, introduced to } \\
\text { North America and to } \\
\text { Australia }\end{array}$ \\
\hline & $\begin{array}{l}\text { Neonectria punicea } \\
\text { (J.C. Schmidt) Castl. } \\
\text { \& Rossman }\end{array}$ & 4 groups of perithecia & $\begin{array}{l}\text { Status undefined } \\
\text { (probably no } \\
\text { vital spores) }\end{array}$ & $\begin{array}{l}\text { Europe, North America, } \\
\text { introduced to New Zealand } \\
\text { and Australia }\end{array}$ \\
\hline & $\begin{array}{l}\text { Quaternaria } \\
\text { quaternata (Pers.) } \\
\text { J. Schröt. }\end{array}$ & Several perithecia & Vital spores & Europe, North America \\
\hline \multirow[t]{2}{*}{$\begin{array}{l}\text { Basidiomycota } \\
\text { (corticioid } \\
\text { basidiomata) }\end{array}$} & $\begin{array}{l}\text { Cylindrobasidium } \\
\text { evolvens (Fr.) Jülich }\end{array}$ & $\begin{array}{l}4 \text { specimens at early stages of } \\
\text { development, single or in patches }\end{array}$ & $\begin{array}{l}\text { Status undefined, } \\
\text { fertile }\end{array}$ & $\begin{array}{l}\text { Europe, Asia and North } \\
\text { America, South America } \\
\text { (Argentina) }\end{array}$ \\
\hline & $\begin{array}{l}\text { Peniophora cinerea } \\
\text { (Pers.) Cooke }\end{array}$ & $\begin{array}{l}30 \text { orbicular, primordial basidiomata } \\
\text { at small distance apart and some } \\
\text { partly confluent }\end{array}$ & $\begin{array}{l}\text { Status undefined, } \\
\text { young and } \\
\text { sterile }\end{array}$ & $\begin{array}{l}\text { Europe, Asia, Africa, } \\
\text { New Zealand, North and } \\
\text { South America }\end{array}$ \\
\hline \multirow{2}{*}{$\begin{array}{l}\text { Basidiomycota } \\
\text { (corticioid, } \\
\text { stereoid } \\
\text { basidiomata) }\end{array}$} & $\begin{array}{l}\text { Chondrostereum } \\
\text { purpureum (Pers.: } \\
\text { Fr.) Pouzar }\end{array}$ & $\begin{array}{l}3 \text { specimens grown up in the absence } \\
\text { of light }\end{array}$ & $\begin{array}{l}\text { Status undefined, } \\
\text { fertile }\end{array}$ & $\begin{array}{l}\text { Cosmopolitan (except } \\
\text { Antarctica) }\end{array}$ \\
\hline & $\begin{array}{l}\text { Stereum hirsutum } \\
\text { (Willd.: Fr.) Gray }\end{array}$ & 2 specimens & $\begin{array}{l}\text { Status undefined, } \\
\text { sterile }\end{array}$ & $\begin{array}{l}\text { Cosmopolitan (except } \\
\text { Antarctica) }\end{array}$ \\
\hline $\begin{array}{l}\text { Basidiomycota } \\
\text { (polyporoid } \\
\text { basidiomata) }\end{array}$ & $\begin{array}{l}\text { Bjerkandera adusta } \\
\text { (Willd.) P. Karst. }\end{array}$ & $\begin{array}{l}5 \text { fragments of basidiomata, one of } \\
\text { them evidently grown up in the } \\
\text { absence of light }\end{array}$ & $\begin{array}{l}\text { Status undefined, } \\
\text { fertile }\end{array}$ & $\begin{array}{l}\text { Cosmopolitan (except } \\
\text { Antarctica) }\end{array}$ \\
\hline \multirow[t]{4}{*}{ Basidomycota } & $\begin{array}{l}\text { Unidentified } \\
\text { basidiomycete } 1\end{array}$ & Several hyphal strands on bark & $\begin{array}{l}\text { Vegetative } \\
\text { structures }\end{array}$ & \\
\hline & $\begin{array}{l}\text { Unidentified } \\
\text { basidiomycete } 2\end{array}$ & Several hyphal strands on bark & $\begin{array}{l}\text { Vegetative } \\
\text { structures }\end{array}$ & \\
\hline & $\begin{array}{l}\text { Unidentified } \\
\text { basidiomycete } 3\end{array}$ & 1 small patch & $\begin{array}{l}\text { Vegetative } \\
\text { structures }\end{array}$ & \\
\hline & $\begin{array}{l}\text { Unidentified } \\
\text { basidiomycete } 4\end{array}$ & 4 small patches & $\begin{array}{l}\text { Vegetative } \\
\text { structures }\end{array}$ & \\
\hline \multicolumn{5}{|l|}{ Insects } \\
\hline \multirow[t]{2}{*}{ Cerambycidae } & $\begin{array}{l}\text { Rhagium mordax De } \\
\text { Geer }\end{array}$ & 1 larva, 2 imago (female) & $\begin{array}{l}\text { Live, all in } \\
\text { hibernation }\end{array}$ & Europe \\
\hline & $\begin{array}{l}\text { Callidium violaceum } \\
\text { Linnaeus }\end{array}$ & 1 larva & $\begin{array}{l}\text { Live, in } \\
\text { hibernation }\end{array}$ & $\begin{array}{l}\text { Palearctic, Near East, } \\
\text { Oriental region }\end{array}$ \\
\hline
\end{tabular}

survive for a period of time in the indoor conditions of a station, they would be unable to complete their life cycle without bark and cannot establish a stable population if decorticated wood is either the only, or the predominant, wood present. The same applies to fungi. Even if some, in particular, ascomycetes, were able to form anamorphic structures and spread in this form, the probability of this situation's arising is low.
No representatives of such anamorphic genera as Cylindrocarpon, Nodullisporium or Libertella (anamorphic stages of Hypoxylon, Nectria and Quaternaria), have been recorded from Antarctica to date (Bridge et al. 2010). Moreover, only soft rot fungi has been observed in the decomposition of wooden structures, mostly old huts, in Antarctica (Blanchette et al. 2004) and it was concluded that the harsh 
climate conditions preclude the development of white and brown rot fungi. This would exclude all wood decomposing Basidiomycota from the biota of Antarctica. None of the recorded fungal taxa is known to cause a soft rot of wood.

It should be pointed out that we can perceive fruit bodies of fungi on the bark relatively easily; however, the presence of fungal hyphae would also be likely inside of the core of the wood, where they might well also spread. This is one of the reasons why only recently prefabricated timber, which has been protected from external factors, should be transported to Antarctic stations, with wood treated in any other way being excluded. The Protocol on Environmental Protection to the Antarctic Treaty states that no species non-native to the Antarctic Treaty area shall be introduced and that every precaution should be taken to prevent the importation of alien organisms (Antarctic Treaty Consultative Parties 1991). Keeping this in mind, the transport of untreated and insecure timber to the Antarctic stations would appear not to be best practice. The management of the "Arctowski" station was informed about the problem and requested to take this into account when preparing supplies for the station.

Acknowledgments The field survey was made possible by the logistical and financial support of the Department of Antarctic Biology, Polish Academy of Sciences. Special thanks are due to expeditionary teams and all persons who accompanied and helped me during the 32nd Polish Antarctic Expedition to "Arctowski" station. We are very grateful to Dr Robert Rossa (Kraków) who confirmed identification of insect's imago and identified larvae. The work is part of the "Aliens in Antarctica" project realized as part of the International Polar Year (IPY) 2007-2008 and recommended by SCAR (Scientific Committee on Antarctic Research) and EBA (Evolution and Biodiversity in Antarctic) programs. This study was supported by the Ministry of Science and Higher Education (special grant no. IPY/27/2007).

Open Access This article is distributed under the terms of the Creative Commons Attribution Noncommercial License which permits any noncommercial use, distribution, and reproduction in any medium, provided the original author(s) and source are credited.

\section{References}

Antarctic Treaty Consultative Parties (1991) Protocol on environmental protection to the Antarctic Treaty. CM 1960. Her Majesty's Stationery Office, London
Blanchette RA, Held BW, Jurgens JA, McNew DL, Harrington TC, Duncan SM, Farrell RL (2004) Wood-destroying soft rot fungi in the historic expedition huts of Antarctica. Appl Environ Microbiol 70:1328-1335

Block W (1984) Terrestrial microbiology, invertebrates and ecosystems. In: Laws RM (ed) Antarctic ecology. Academic Press, London, pp 163-236

Bridge PD, Denton GJ (2007) Isolation of diverse viable fungi from the larvae of the introduced chironomid Eretmoptera murphyi on Signy Island. Polar Biol 30:935-937

Bridge PD, Hughes KA (2010) Conservation issues for Antarctic fungi. Mycol Balcan 7:11-14

Bridge PD, Spooner BM, Roberts PJ (2010) List of non-lichenized fungi from the Antarctic region (Version 2.3.3; January 2010). http://www.antarctica.ac.uk//bas_research/ data/access/fungi. Accessed Dec 2010

Convey P (2006) Antarctic climate change and its influences on terrestrial ecosystems. In: Bergstrom DM, Convey P, Huiskes AHL (eds) Trends in Antarctic terrestrial and limnetic ecosystems: Antarctica as a global indicator. Springer, Dordrecht, pp 253-272

Convey P, Frenot Y, Gremmen N, Bergstrom DM (2006) Biological invasions. In: Bergstrom DM, Convey $\mathrm{P}, \mathrm{Hu}-$ iskes AHL (eds) Trends in Antarctic terrestrial and limnetic ecosystems: Antarctica as a global indicator. Springer, Dordrecht, pp 193-220

Council of Managers of National Antarctic Programs (COMNAP) (2010) Antarctic facilities. http://www.comnap.aq/ facilities. Accessed Dec 2010

Frenot Y, Chown SL, Whinam J, Selkirk PM, Convey P, Skotnicki M, Bergstrom DM (2005) Biological invasions in the Antarctic: extent, impacts and implications. Biol Rev 80:45-72

Hughes KA, Convey P (2010) The protection of Antarctic terrestrial ecosystems from inter- and intra-continental transfer of non-indigenous species by human activities: A review of current systems and practices. Glob Environ Change 20:96-112

Hughes KA, Worland MR (2010) Spatial distribution, habitat preference and colonisation status of two alien terrestrial invertebrate species in Antarctica. Antarct Sci 22:221-231

Hughes KA, Walsh S, Convey P, Richards S, Bergstrom DM (2005) Alien fly populations established at two Antarctic research stations. Polar Biol 28:568-570

Hughes KA, Ott S, Bolter M, Convey P (2006) Colonisation processes. In: Bergstrom D, Convey P, Huiskes AHL (eds) Trends in Antarctic terrestrial and limnetic ecosystems. Springer, Dordrecht, pp 35-54

Hughes KA, Lee JE, Ware C, Kiefer K, Bergstrom DM (2010) Impact of anthropogenic transportation to Antarctica on alien seed viability. Polar Biol 33:1125-1130

International Association of Antarctica Tour Operators (IAATO) (2010) Tourism statistics. http://www.iaato.org/ tourism_stats.html. Accessed Dec 2010

Magan N (2007) Fungi in extreme environments. In: Kubicek CP, Druzhinina IS (eds) Environmental and microbial relationships, 2nd edn. The Mycota IV. Springer-Verlag, Berlin, Heidelberg, pp 85-103

Olech M (2004) Lichens of King George Island, Antarctica. Institute of Botany, Jagiellonian University, Cracow 
Osyczka P (2010) Alien lichens unintentionally transported to the "Arctowski" station (South Shetlands, Antarctica). Polar Biol 33:1067-1073

Pegler DN, Spooner BM, Smith RIL (1980) Higher fungi of Antarctica, the subantarctic zone and Falkland Islands. Kew Bulletin 35:499-562

Ruisi S, Barreca D, Selbmann L, Zucconi L, Onofri S (2007) Fungi in Antarctica. Rev Environ Sci Biotechnol 6:127-141

Sala OE, Chapin FS, Armesto JJ, Berlow E, Bloomfield J, Dirzo R, Huber-Sanwald E, Huenneke LF, Jackson RB,
Kinzig A, Leemans R, Lodge DM, Mooney HA, Oesterheld M, Poff NL, Sykes MT, Walker BH, Walker M, Wall DH (2000) Global biodiversity scenarios for the year 2100. Science 287:1770-1774

Vernon P, Vannier G, Trehen P (1998) A comparative approach to the entomological diversity of Polar Regions. Acta Oecol 19:303-308

Whinam J, Chilcott N, Bergstrom DM (2005) Subantarctic hitchhikers: expeditioners as vectors for the introduction of alien organisms. Biol Conserv 121:207-219 